\title{
Morphological Diversity of the Ovaries of the Mexican Teleost Fishes
}

\author{
Diversidad Morfológica de los Ovarios de los Peces Teleósteos de México
}

"Abraham Kobelkowsky

KOBELKOWSKY, A. Morphological diversity of the ovaries of the Mexican teleost fishes. Int. J. Morphol., 30(4):1353-1362, 2012.

SUMMARY: The morphological diversity of the ovaries from a total of 90 species of teleosts in the Mexican fauna was analyzed. Ovaries were classified according to the following characters: their number, symmetry, fusion grade, trajectory, cross section, and topographical location. The fusion of both left and right ovaries was the character showing most diversity, mainly in the Cyprinodontiformes and its tendency to the viviparity. However, the most notably character was the extravisceral development of the ovaries in the Pleuronectiformes, implying the forward orientation of the gonoduct and the forward position of the female genital opening. The urogenital system of a typical perciform, Bairdiella chrysoura is proposed as a morphological pattern of the Teleostei.

KEY WORDS: Osteichthyes; Genital system; Gonads; Anatomy.

\section{INTRODUCTION}

Teleostei are the most diverse and abundant group of Osteichthyes (bony fishes), with about 26,840 species, grouped in 40 orders (Nelson, 2006), from which 30 are represented in the Mexican fauna.

Ovaries and testes are typically paired organs in teleosts, generally suspended by means of mesenteries from the visceral cavity roof or from the gas bladder. During the reproductive season, ovaries are big and yellowish organs, and may represent about $30 \%$ to $70 \%$ the body weight, whereas testes are whitish organs not more than $12 \%$ the body weight (Moyle \& Cech, 1988).

Only a few species are hermaphrodite, for the presence of ovotestis. Although studies on reproductive biology are numerous, articles about gonads morphology are scarce. Teleostean gonads (ovaries and testes) are in general described by Gérard (1954); Young (1962); Romer (1962); Lagler et al. (1977), Chiasson (1980), and Nagahama (1983), whereas ovaries in particular, are studied by Dodd (1977), Begovac \& Wallace (1987), Selman et al. (1991), Kobelkowsky \& Alva-García (2000), Parenti \& Grier (2004), Uribe et al. (2005), and Kobelkowsky (1999, 2000, 2004, 2005). Among the scarce articles dealing with the ovarian germinal epithelium, is that of Grier (2000) in a representative of the Centropomidae.
Considering the high diversity of fishes in the Mexican Republic and the necessity of a description of the gross anatomy of the ovaries, supporting studies of reproductive biology and fisheries, the objective of the present study is describe the morphological pattern of the female reproductive system and its diversity.

\section{MATERIAL AND METHOD}

Specimens of representative species of the main teleosts orders from the Mexican icthyofauna were examined. Fishes were collected by means of various fishing arts, from lakes, rivers, costal lagoons, and littorals from the Gulf of Mexico and the Mexican Pacific. Specimens were fixed in formalin 10\%, and preserved in ethylic alcohol $70 \%$.

In order to expose the urogenital system of the teleosts with laterally flattened body, the left side of the body was desquamated, from the opercle until the anal fin. The skin and the axial musculature were removed to expose the epipleural and pleural ribs. Both kinds of ribs, pleural and epipleural, were disarticulated, and the parietal peritoneum removed, in order to expose the visceral cavity. In depressed body species, the ventral area was desquamated, from the 
scapular girdle until the anus, and then the skin and axial musculature were removed.

The digestive system was removed by means of a cross section of the esophagus and the rectum, as well as, cutting their mesenteries and blood vessels, and the gas bladder was removed from its attachment on the vertebral column, or if the case from the pleural ribs. In lower teleosts, the pneumatic duct was cut.

In order to recognize the topographical relationships of the ovaries, the red snapper Lutjanus griseus was selected as a morphological pattern.

Three morphological situations of the ovarian suspension, were recognized. To evaluate the morphological diversity of the ovaries, the following aspects were considered: a) amount of ovaries, b) symmetry, c) grade of fusion between each other, d) trajectory, e) cross section aspect, f) localization, and g) presence of ovotestis.

Figures were made by means of a camera lucida coupled to a stereoscopic microscope Leica Wild M3Z.

The anatomic analysis of the ovaries were made in adult specimens corresponding to the following 90 species, 88 genera, 56 families, and 20 orders of Teleostei: Order Elopiformes: Elops saurus (Elopidae); Order Anguilliformes: Gymnothorax ocellatus (Muraenidae), Ophichthus gomesii (Ophichthidae), Ariosoma anale (Congridae), Hoplunnis sp. (Nettastomatidae); Order Clupeiformes: Harengula jaguana, Brevoortia patronus, Dorosoma cepedianum (Clupeidae), Anchoa mitchilli, Cetengraulis edentulus (Engraulidae); Order Cypriniformes: Hybopsis boucardi, Carpiodes carpio (Cyprinidae); Order Characiformes: Astyanax fasciatus (Characidae); Order Siluriformes: Ictalurus balsanus (Ictaluridae), Cathorops melanopus, Ariopsis felis, Bagre marinus (Ariidae), Rhamdia guatemalensis (Pimelodidae); Order Salmoniformes: Oncorhynchus mykiss (Salmonidae); Order Aulopiformes: Synodus foetens (Synodontidae); Order Batrachoidiformes: Opsanus beta, Porichthys plectrodon, Batrachoides boulengeri (Batrachoididae); Order Lophiiformes: Antennarius scaber (Antennariidae), Halieutichthys auleatus, Ogcocephalus radiatus (Ogcocephalidae); Order Mugiliformes: Mugil cephalus, Agonostomus monticola (Mugilidae); Order Atheriniformes: Chirostoma humboldtianum, Membras vagrans, Menidia beryllina (Atherinopsidae); Order Beloniformes: Strongylura marina, Strongylura notata, Strongylura timиси (Belonidae), Hyporhamphus roberti (Hemiramphidae), Cypselurus callopterus (Exocoetidae); Order Cyprinodontiformes: Fundulus grandis (Fundulidae),
Anableps dowei (Anablepidae), Gambusia regani, Poeciliopsis infans, Belonesox belizanus (Poeciliidae), Goodea atripinnis (Goodeidae); Lucania parva, Cyprinodon variegatus (Cyprinodontidae); Order Gasterosteiformes: Syngnathus scovelli (Syngnathidae); Order Synbranchiformes: Synbranchus marmoratus (Synbranchidae); Order Scorpaeniformes: Scorpaena plumieri (Scorpaenidae), Prionotus maculatus (Triglidae); Order Perciformes: Centropomus undecimalis (Centropomidae), Epinephelus guttatus (Serranidae), Micropterus salmoides (Centrarchidae), Lutjanus griseus (Lutjanidae), Eugerres plumieri, Eucinostomus argenteus, Diapterus auratus, Gerres cinereus (Gerreidae), Conodon nobilis (Haemulidae), Archosargus probatocephalus (Sparidae), Bairdiella chrysoura, Stellifer lanceolatus, Cynoscion nothus, Menticirrhus saxatilis, Micropogonias undulatus, Umbrina coroides (Sciaenidae), Prognathodes aya (Chaetodontidae), Herichthys cyanoguttatus, Petenia splendida (Cichlidae), Thalassoma lucasanum (Labridae), Hypsoblennius henzi (Blennidae), Dormitator maculatus, Gobiomorus dormitor (Eleotridae), Evorthodus lyricus, Gobionellus oceanicus, Bathygobius soporator (Gobiidae), Trichiurus lepturus (Trichiuridae), Sphyraena barracuda (Sphyraenidae) ; Peprilus triacanthus (Stromateidae); Order Pleuronectiformes: Bothus robinsi (Bothidae), Citharichthys spilopterus, Syacium papillosum, Cyclopsetta chittendeni (Paralichthyidae), Pleuronichthys ritteri (Pleuronectidae), Achirus lineatus, Trinectes maculatus, Gymnachirus texae (Achiridae), Symphurus plagiusa, (Cynoglossidae); Order Tetraodontiformes: Balistes capriscus (Balistidae), Diodon hystrix, Chilomycterus schoepfii (Diodontidae), Sphoeroides testudineus (Tetraodontidae).

\section{RESULTS}

Visceral cavity and morphology of the ovaries of Bairdiella chrysoura (Fig. 1).

The kidneys of $B$. chrysoura are located ventrally to the precaudal vertebrae. From the posterior end, near the first anal pterygiophore, the archinephric ducts descend until they reach the urinary bladder. From this structure, the urinary duct in females and the urogenital duct in males start.

The gas bladder is long and located ventrally to the kidney, and it is divided into two chambers. The ovaries of B. chrysoura are long and suspended from the gas bladder by means of the mesovaria. The contact of each mesovarium to the ovary is close to the medial border and coincides with the trajectory of the ovarian artery and vein. 


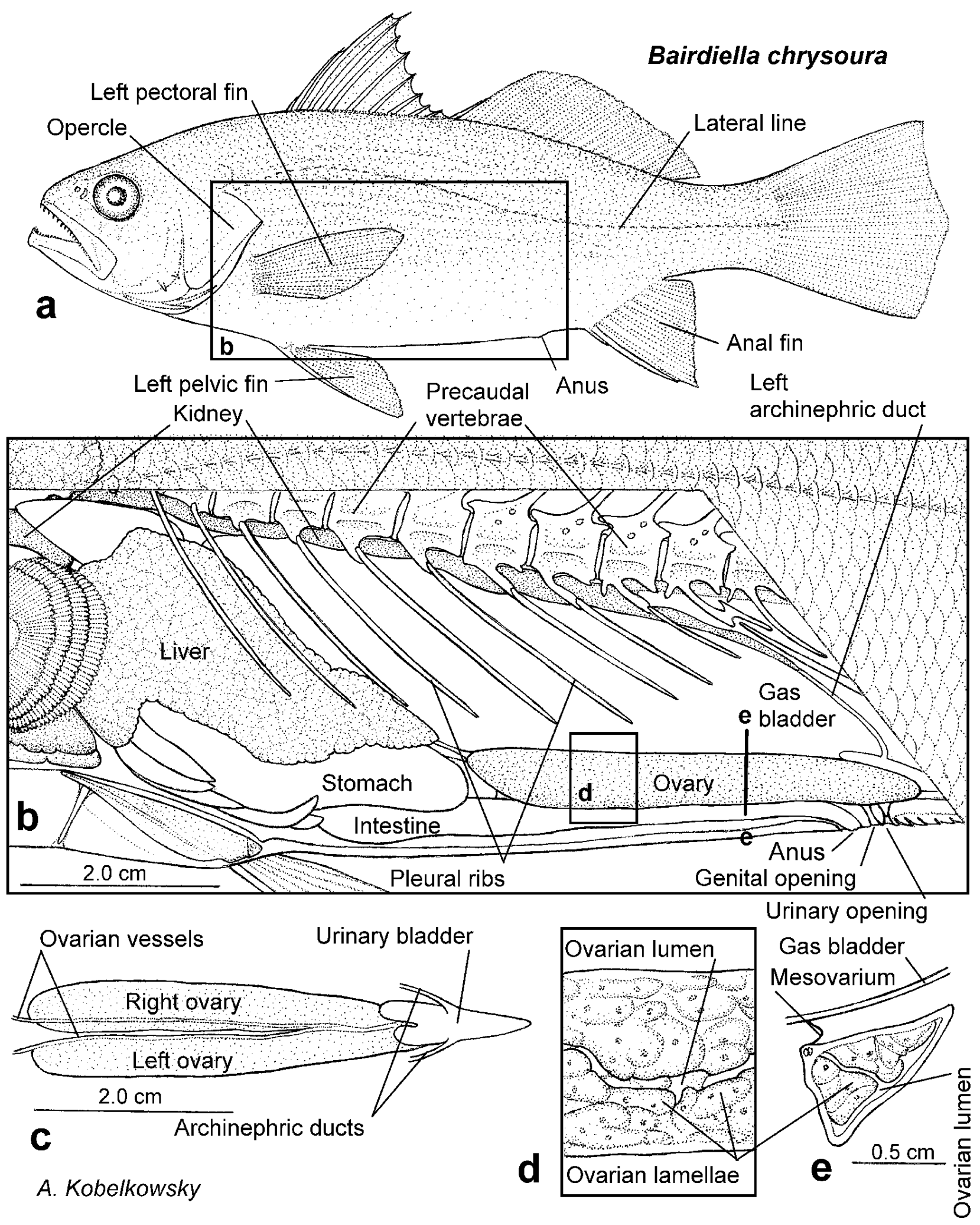

Fig. 1. The urogenital system of Bairdiella chrysoura. a) Left lateral view of the specimen. b) Left lateral view of the visceral cavity, showing their organography. c) Dorsal view of the ovaries. d) Lateral view of a portion of the ovary, after removing the lateral wall. e) Cross section of the ovary (transept $\mathrm{e}-\mathrm{e}$ ). 
The female gonads show the typical cystovarian condition, defined as the presence of a cavity, whose walls continue backwards to form the gonoduct, that leads to the genital opening, behind the anus. Both ovaries fuse together at the posterior portion.

The ovarian stroma is formed by the ovigerous lamellae, originating from the medial walls of the gonad, with exception of the lateral wall. As the ovary mature, such lamellae occupy all the lumen, therefore, ovulation occurs into the ovarian lumen.

Morphological diversity of the ovarian suspension. In most of the examined species ovaries are suspended by means of the mesovaria, from the gas bladder, as is shown in $B$. chrysoura (Fig. 1e).

In the species with a short gas bladder, ovaries are suspended in part from this organ, and the rest directly from the roof of the visceral cavity, such as in the catfishes, $C$. melanopus and $R$. guatemalensis, and in the toadfish $O$. beta.

In the species with no gas bladder, ovaries are suspended directly from the roof of the visceral cavity, such as in the lizardfish S. foetens, the goby G. oceanicus, and the batfish $O$. radiatus.

In species with widely fused ovaries, such as the tiro G. atripinnis, a medial mesovarium is observed, and follows through the dorsal surface, the trajectory of the interovarian septum. In species in which the gas bladder do not persists and have extra visceral ovaries, as the flatfishes (order Pleuronectiformes), mesovaria are not observed.

\section{Morphological diversity of the ovaries (see Table I).}

According to the number of ovaries, the categories of a unique ovary and of paired ovaries are recognized. The needlefish S. marina (Fig. 2a) and the eel S. marmoratus have only the right ovary, which is very long. The most examined teleostean species showed two ovaries, inclusive the needlefishes $S$. notata y $S$. timucu (Fig. 2b).

According to the symmetry there are symmetric and asymmetric ovaries. Most of the teleosts species fall in the first category, with just small size differences between both ovaries. In some species notable differences in size and shape are shown, such as the anchovy A. mitchilli with the right ovary smaller and the right one bigger and growing below intestine.

According to the amount of fusion of both ovaries, two categories are identified: the teleosts with totally separated ovaries and those with ovaries with some grade of fusion. The eels $O$. gomesii (Fig. 2c) and A. anale, have separated long and parallel ovaries, with no defined gonoduct.

In the rest of the examined teleosts, both ovaries are fused at the posterior portion, as is observed in the silver croacker B. chrysoura (Fig. 2e), in the mullet M. cephalus, and the toadfishes $O$. beta (Fig. 3d) and P. plectrodon.

In some teleosts both ovaries are completely fused, recognizing two groups according to the presence or absence of the intraovarian septum. In the butterfly P. aya and the tiro G. atripinnis (Fig. 2f) an interovarian septum is remained. While in $P$. aya the septum is straight, in $G$. atripinnis is extensive and with many folds, between which the embryos are located. The contact of the mesovarium with the dorsal surface of the ovary coincides with the trajectory of the ovarian vessels and with the contact of the interovarian septum with the roof of the organ.

In species of the Poeciliidae family, such as the guayacón G. regani (Fig. 3g) and the guapote of the Lerma $P$. infans, both ovaries fuse together, not remaining an interovarian septum. This sacular gonad contains the embryos and grows asymmetrically on the right side of the digestive tract and liver.

According to the trajectory, the following categories of teleosts are identified: a) with ovaries paralleled each other, b) with ovaries paralleled in part and divergent in the rest, and c) ovaries evidently divergent.

In various teleosten, both ovaries have a parallel position, with no contact each other, such as in the pipefish $S$. scovelli (Fig. 3a). Other species have close contact in the most length of the ovaries, such as the catfish of the Ariidae family, C. melanopus (Fig. 3b), A. felis, and B. marinus.

With parallel and divergent ovaries, the catfish $R$. guatemalensis is found, in which the posterior portions are paralleled, however, during ovarian maturation, the gas bladder separate them each other (Fig. 3c), becoming divergent.

Ovaries fused in the last portion, and with the rest widely divergent are observed in species such as $O$. beta (Fig. 3d), P. plectrodon (Batrachoididae), and the grouper E. guttatus. The divergence is produced by the interposition of the gas bladder.

According to the cross section of the ovaries, teleosts are grouped into two categories: with triangular-circular section and flattened ovaries. 


\section{A. Kobelkowsky}

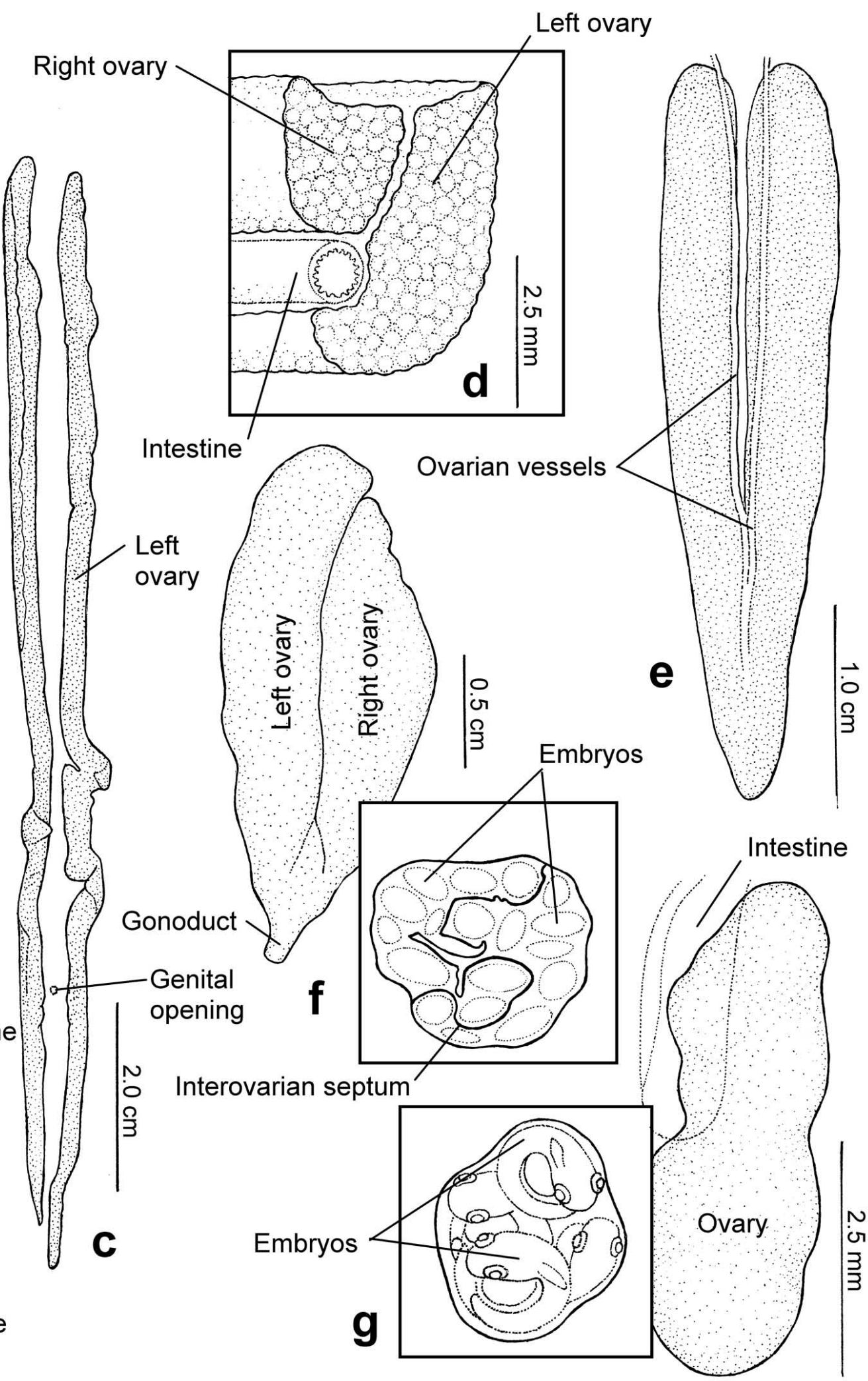

Fig. 2. Morphological diversity of the ovaries of teleosts. a) Dorsal view of the unique ovary, and cross section of the visceral cavity of Strongylura marina. b) Cross section of the visceral cavity of Strongylura notata. c) Ventral view of the ovaries of Ophichthus gomesii. d) Cross section of the ovaries of Anchoa mitchilli. e) Dorsal view of the ovaries of Bairdiella chrysoura. f) Dorsal view and cross section of the ovaries of Goodea atripinnis. g) Dorsal view and cross section of the ovary of Gambusia regani. 
Table I. Classification of the teleosts fishes according to the ovaries characters.

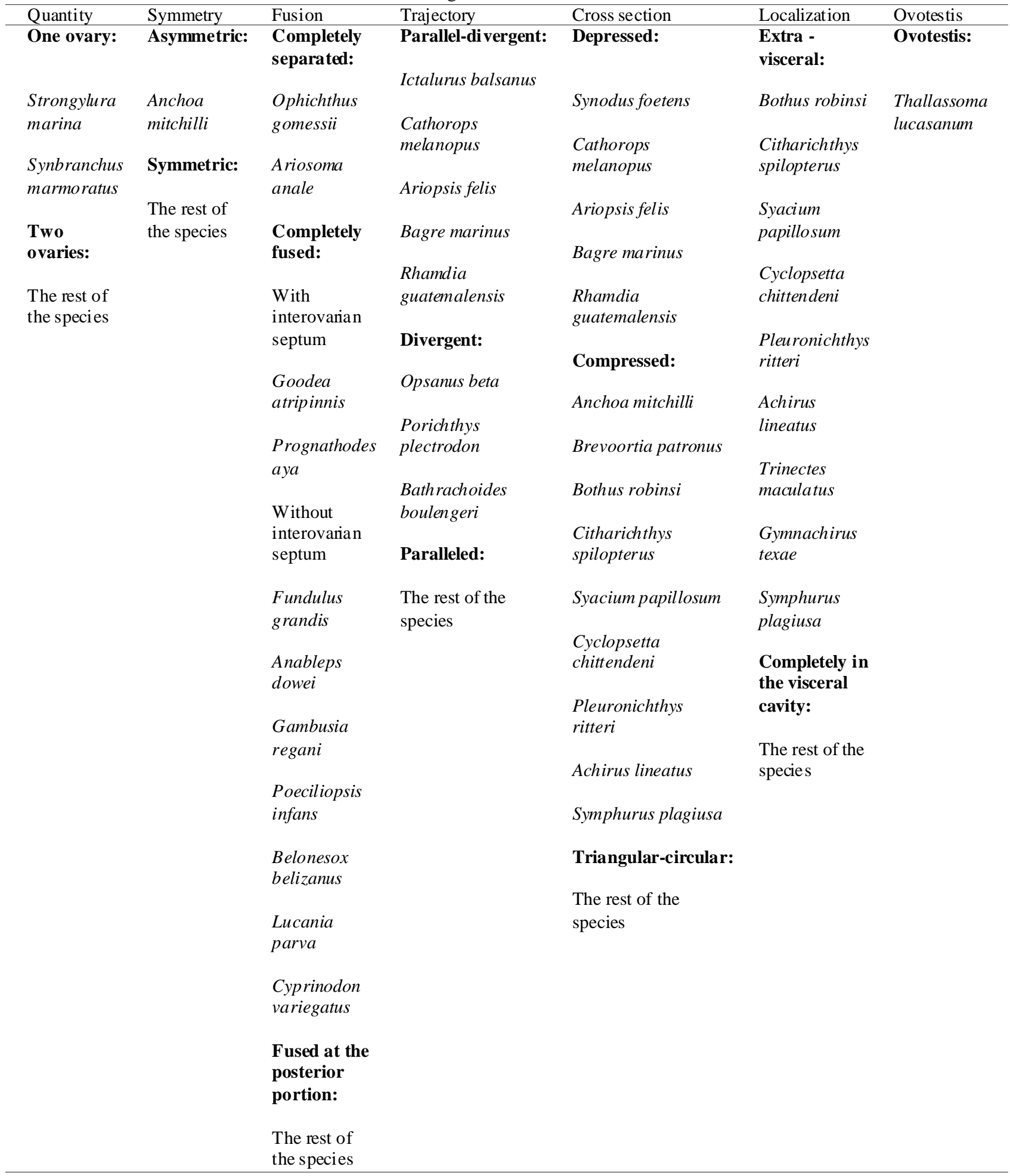

In most of the species, such as in B. chrysoura ovaries are triangular in cross section (Fig. 1d), at the beginning of the maturation, own the contact with the gas bladder, the intestine and the wall of the visceral cavity. Ripe ovaries are cylindrical, and are circular in cross section as a result of the increase of the oocytes diameter. 


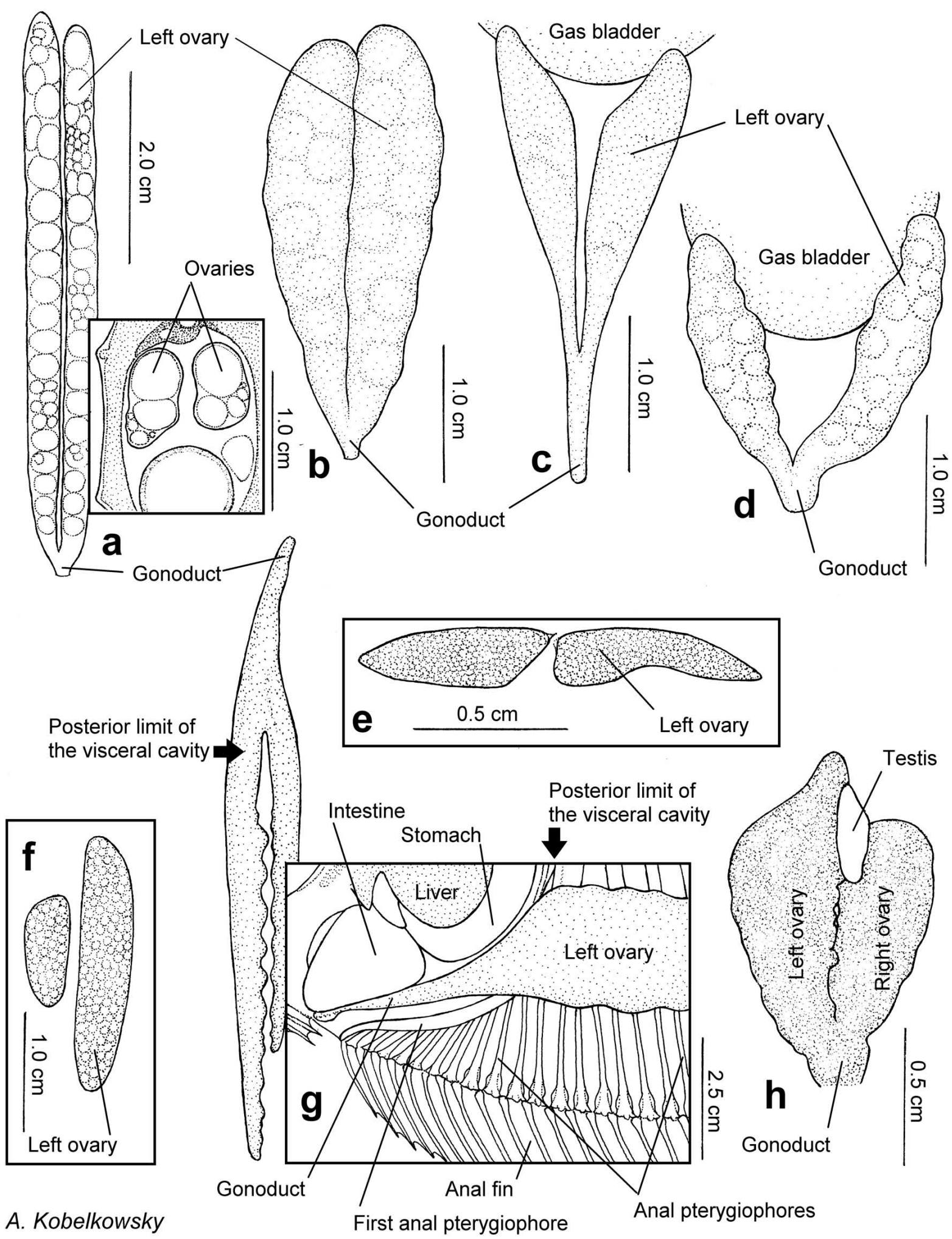

Fig. 3. Morphological diversity of the ovaries of teleosts. a) Ventral view of the ovaries, and cross section of the visceral cavity of Syngnathus scovelli. b) Ventral view of the ovaries of Cathorops melanopus. c) Ventral view of the ovaries of Rhamdia guatemalensis. d) Ventral view of the ovaries of Opsanus beta. e) Cross section of the ovaries of Synodus foetens. f) Cross section of the ovaries of Bothus robinsi. g) Dorsal view of the ovaries, and left lateral view of the visceral cavity and anal fin of Bothus robinsi. h) Dorsal view of the ovotestis of Thallasoma lucasanum. 
Teleosts with flattened ovaries are grouped into two categories: a) with depressed or dorso-ventrally flattened ovaries, and b) with laterally flattened ovaries. Depressed ovaries are found in species with depressed body such as the lizardfish S. foetens (Fig. 3e), and in immature stages in fusiform species, but with the visceral cavity depressed, like C. melanopus. Ovaries are laterally flattened (compressed) in species with the body compressed as A. mitchilli (Fig. 2d), the Gulf menhaden B. patronus and the flounders $A$. lineatus, C. chittendeni, and B. robinsi (Fig. 3f).

According to the position of the ovaries, the majority of teleosts have the female gonads completely in the visceral cavity (Fig. 1a), whereas in the Pleuronectiformes, such as B. robinsi typically the ovaries develop in their most length out the visceral cavity (Fig. 3g), between the pterygiophores of the anal fin, the hemal spines of the caudal vertebrae, and the muscles moving the rays of the anal fin. Due to in the Pleuronectiformes the anal fin starts notable forward, and the first anal petrygiophore are curved, the anus and genital and urinary openings, are located in a very anterior position. This implies that being the ovaries in a posterior position, the gonoduct run forward.

The ovotestis is recognized in T. lucasanum (Fig. 3h), in which the ovarian portion is bigger than the testicular. Both ovaries are fused together in the posterior portion. The testis is notably short and is located on the anterior part and between the ovaries.

\section{DISCUSSION}

According to Parenti \& Grier studies on gross anatomy of osteichthyans have focused on a few numbers of commercial or recreational fishing species.

In the present study of 90 species of Teleostei, corresponding to 88 genera, 56 families and 20 orders, a morphological pattern was defined in B. chrysoura. However a relatively high diversity of the macroscopic morphology of ovaries is recognized.

As a morphological pattern of the ovaries of the Teleostei, is recognized in the Perciformes, as the silver croaker, Bairdiella chrysoura, consisting of the presence of two female gonads, about the same size, suspended from the gas bladder by means of the two mesovaria, and fused at the posterior portion, to give rise a short gonoduct that leads to the genital opening. The hollow character, with numerous ovigerous lamellae described by Dodd is found in the examined species; however, a relatively high diversity of macroscopically anatomic situations is observed.

Seven morphological features were taking in account: the ovarian suspension, the number of ovaries, the asymmetry, the grade of fusion, the trajectory, the aspect in cross section, and the localization.

The ovarian suspension of the examined teleosts fits in the general pattern of the vertebrates that implies the mesovaria. However, while mesovaria are fixed from the roof of the visceral cavity in the vertebrates in general, in teleosts are fixed from the gas bladder, with the exception of some benthic teleosts with no gas bladder.

It is outstanding the atypical condition of the reduction of the ovaries to a single gonad in S. marina (Belonidae) and S. marmoratus (Synbranchidae), whereas in other species of the genus Strongylura (S. notata and $S$. tітиси) there are two ovaries. This condition is considered in the taxonomy of Belonidae.

Two reproductive adaptations are identified in species with anguiliform body: a) the reduction to a single and long gonad, and b) the presence of two long and slender ovaries, extended backwards beyond the anus and genital opening.

Although teleosts in general normally have one ovary slightly longer than the other, a remarkable asymmetry is observed in the ovarian size in the Engraulidae.

The ovarian character producing most morphological diversity is the fusion of the two female gonads, recognizing four grades of fusion. However, the most frequent condition is the fusion of the last part of the ovaries and its continuity as the gonoduct. In the other hand, the extreme fusion of both ovaries was identified in representative species of the order Cyprinodontiformes, and it is a feature extensively considered by authors, such as Wourms et al., (1988), and Uribe et al., concerning the viviparity of Poeciliidae, Goodeidae and Anablepidae.

The presence of a short but wide gas bladder is identified as the feature producing the ovarian divergence, characteristic of Pimelodidae and Batrachoididae.

A direct relation between the flattened body or the visceral cavity and the flattened aspect of ovaries is recognized in an abundant group of teleosts. Ovaries laterally flattened correspond to compressed bodies in Clupeiformes and Pleuronectiformes, while ovaries dorsoventrally flattened correspond to depressed bodies or visceral cavities. 
The most specialized morphological situation of the ovaries of all the examined teleosts is found in the Pleuronectiformes, own to the great reduction of the visceral cavity, and the consequent backward development of the ovaries, into the so-called by Norman (1934) "secondary body cavities", between the hypaxial musculature, anal fin musculature, anal perygiophores and hemal spines.

An unusual feature is the association of the ovaries with the testis, in the so-called ovotestis in the hermaphrodite species of T. lucasanum (Labridae), and described by Warner.

KOBELKOWSKY, A. Diversidad morfológica de los ovarios de los peces teleósteos de México. Int. J. Morphol., 30(4):1358-1362, 2012.

RESUMEN: Se reconoció una diversidad morfológica de los ovarios dentro de un conjunto de 90 especies de teleósteos de la fauna mexicana. Se clasificaron los ovarios de acuerdo con los siguientes caracteres: número de ovarios, su simetría, el grado de fusión entre sí, su trayectoria, el aspecto en sección transversal y su ubicación topográfica. Se reconoce el carácter de la fusión de ambos ovarios entre sí, como el que presentó la mayor diversidad de situaciones, sobresaliendo la tendencia a la total fusión dentro de los Cyprinodontiformes y su relación con la viviparidad. Sin embargo, el carácter más notable fue el desarrollo extravisceral de los ovarios en los Pleuronectiformes, que implica la orientación del gonoducto hacia delante y la posición adelantada de la abertura genital. Se propone como patrón morfológico del sistema urogenital de los Teleostei a un típico perciforme, Bairdiella chrysoura.

PALABRAS CLAVE: Osteictios; Sistema genital; Gónadas; Anatomía.

\section{REFERENCES}

Begovac, A. W. \& Wallace, R. A. Ovary of the pipefish, Syngnathus scovelli. J. Morphol., 193:117-33, 1987.

Chiasson, R. B. Laboratory anatomy of the perch. Dubuque, W M. C. Brown Company Publishers, 1980.

Dodd, J. M. The structure of the ovary of nonmmamalian vertebrates. In: The ovary. Zuckermann, L. \& Weir, B. J. (Eds). London, Academic Press, 1977. pp 219-63.

Gérard, P. Organes uro-genitaux. In: Grassé, P. P. (Ed.). Traité de Zoologie. Anatomie, Systematique, Biologie. Paris, Masson et Cie, 1954. pp.1565-83. Tome XII.

Grier, H. Ovarian germinal epithelium and folliculogenesis in the common snook, Centropomus undecimalis (Teleostei: Centropomidae). J. Morphol., 243(3):265-81, 2000.

Kobelkowsky, A. El sistema urogenital de los géneros Bairdiella y Stellifer (Pisces: Sciaenidae). Rev. Soc. Mex. Hist. Nat., 49:15362, 1999.

Kobelkowsky, A. Sistema urogenital de la familia Achiridae (Pisces: Pleuronectiformes) del Golfo de México. Hidrobiológica, 10:51-60, 2000.

Kobelkowsky, A. Sexual dimorphism of the flounder Bothus robinsi (Pisces: Bothidae). J. Morphol., 260:165-71, 2004.

Kobelkowsky, A. General anatomy and sexual dimorphism of Goodea atripinnis (Teleostei: Goodeidae). In: Uribe, M. C. \& Grier, H. J. (Eds.). Viviparous fishes, M.C. Homestead, Florida, New life Publications, 2005. pp.483-98.
Kobelkowsky, A. \& Alva-García, A. Anatomía sexual de Gambusia regani (Pisces: Poeciliidae). An. Inst. Biol., Univ. Nal. Autón. México, Ser. Zoología, 71:133-42, 2000.

Lagler, K. F.; Bardach, J. E.; Miller, R. R. \& May Passino, D. R. Ictiología. México, AGT, 1977.

Moyle, P. B. \& Cech, J. J. Fishes. An Introduction to ichthyology. New Jersey, Prentice Hall, Englewood Cliffs, 1988.

Nagahama, Y. The functional morphology of teleost gonads. In: Hoar, W. S. \& Randall, D. J. (Eds.). Fish Physiology. London, Academic Press, 1983. pp.223-75.

Nelson, J. S. Fishes of the world. New York, John Wiley y Sons Inc., 2006.

Norman, J. R. A systematic monograph of the flatfishes (Heterosomata). 1. Psettodidae, Bothidae, Pleuronectidae. London, British Museum, 1934.

Parenti, L. R. \& Grier, H. J. Evolution and phylogeny of gonad morphology in bony fishes. Integr. Comp. Biol., 44:333-48, 2004.

Romer, A. S. The Vertebrate Body. Philadelphia, W.B. Saunders Company, 1962.

Selman, K.; Wallace, R. A. \& Player, D. Ovary of the seahorse, Hippocampus erectus. J. Morphol., 209:285-304, 1991.

Uribe, M. C.; De la Rosa-Cruz, G. \& García-Alarcón, A. The ovary of viviparous teleosts. Differences between the ovaries of 
KOBELKOWSKY, A. Morphological diversity of the ovaries of the Mexican teleost fishes. Int. J. Morphol., 30(4):1353-1362, 2012.

Goodea atripinnis and Ilyodon whitei (Goodeidae). In: Viviparous Fishes. Uribe, M. C. \& Grier, H. J. (Eds.). Homestead, Florida, New Life Publications, 2005. pp.217-35.

Warner, R. Mating systems, sex change and sexual demography in the rainbow wrasse, Thalassoma lucasanum. Copeia, 1982(3):653-61, 1982.

Wourms, J. P.; Grove, B. D. \& Lombardi, J. The maternalembryonic relationships in viviparous fishes. In: Fish Physiology, Vol. XI. Hoar, W. S. \& Randall, D. J. (Eds.). London, Academic Press, 1988. pp.1-134.

Young, J. Z. The life of vertebrates. Oxford, Clarendon Press, 1962.

\author{
Dirección para correspondencia: \\ Abraham Kobelkowsky \\ Laboratorio de Peces \\ Departamento de Biología \\ Universidad Autónoma Metropolitana \\ Unidad Iztapalapa \\ Av. San Rafael Atlixco 186, \\ Col. Vicentina, Iztapalapa \\ Apartado Postal 55-535. 09340 \\ México, D.F. \\ MÉXICO
}

Email: akd@xanum.uam.mx

Received: 08-12-2011

Accepted: 13-04-2012 